\title{
THE HUMAN LEARNING PROCESS IN THE ORGANIZATIONAL CONTEXT
}

\section{ORIGINAL ARTICLE}

SILVA, Lilian Reis da ${ }^{1}$

SILVA, Lilian Reis da. The human learning process in the organizational context. Revista Científica Multidisciplinar Núcleo do Conhecimento. Year. 06, Ed. 10, Vol. 08, pp. 17-30. October 2021. ISSN: 2448-0959, Access link: https://www.nucleodoconhecimento.com.br/education/human-learning-process, DOI: 10.32749/nucleodoconhecimento.com.br/education/human-learning-process

\section{ABSTRACT}

This article, elaborated through bibliographic research, has as a fundamental question the way individuals learn and interact in the context of organizations. Aiming to address how individual learning contributes to organizational learning among individuals. From the literature analyzed, it was found that the knowledge and knowledge acquired individually by people must be added to the communication, interaction and sharing skills with colleagues, within the scope of organizations, so that together they learn the culture, internal system, objectives and practices inherent to it, in order to achieve the existing goals.

Keywords: Human capital, Knowledge, Skills, Professional Performance, Organizational Learning.

\section{INTRODUCTION}

Throughout their professional lives, all individuals have numerous learning opportunities beyond that conventional - and individual - as, for example, new ways

\footnotetext{
${ }^{1}$ Postgraduate in Business Management, Economist, Accounting Technique.
}

RC: 100493

Available in: https://www.nucleodoconhecimento.com.br/education/human-learningprocess 
of working, which are often different from one company to another. Such learning can also occur from new readings, specialization courses or the identification of videos on the Internet, on topics inherent to the area of activity. There is also the networking itself.

Given the volume of information and modernizations that global society lives, Bezerra and Oliveira (2006, s.p.) refer Guns (1998, p.7) to confirm that the volume of information today is so large that "executives, managers and frontline workers also face gigantic amounts of information."

In turn, the valorization of individuals in a society that today already recognizes that human capital is the most precious asset within organizations (CHIAVENATO, 2020), workers left that role of simple executors of previously defined tasks, moving to the role of internal clients, who require constant updates to better perform their functions, whose results must meet the goals established by the direction of such organizations.

This reality - not so recent - brings to everyone the concept about organizational learning, which, according to Guns (1998, p. 33, apud BEZERRA and OLIVEIRA, 2006, s.p.), consists of acquiring "knowledge, skills, values, convictions and attitudes that increase the maintenance, growth and development of the organization".

Therefore, the aim of this article is to address how individual learning contributes to organizational learning among individuals.

\section{THE LEARNING PROCESSES OF INDIVIDUALS}

Learning consists of the act of the individual acquiring knowledge, since "it is the nature of knowledge that he changes fast and that the certainties of today become the absurdities of tomorrow" (DRUCKER, 1999, p.121).

RC: 100493

Available in: https://www.nucleodoconhecimento.com.br/education/human-learningprocess 
Learning in an ever-changing world is not an easy thing, and it is essential - in modern times - that professionals from all areas keep learning. Fleury and Fleury (2001, apud MENEZES et al., undated, p. 2) teach that "learning is considered as a process of change, triggered by various stimuli, mediated by emotions, which may or may not manifest itself in changing behavior of the individual".

According to the Houaiss Dictionary of the Portuguese Language (HOUAISS, 2015, p. 74), learning is "act, duration and experience, action of learning a craft or profession" and learning is "acquiring practical skill knowledge, having a better understanding of (something), by intuition, experience or coexistence [...]".

To Bruni; Turrioni and Stano (2005, p.190), it is a psychological process that is fundamental to human survival, which allows it to adapt to the environment in which it lives, and even conquering moral, intellectual and professional growth. Menezes et al. (undated, p.2) report Abbad and Borges-Andrade (2004, p.238), to highlight that "learning is a psychological process that occurs at the individual level.

From the perspective of Julius (2003), the great question related to learning is the need for people to learn to learn, so that they can always learn. It happens that to learn individuals seek knowledge through information, which, in turn, allows people to reach new knowledge through choice, selection, assimilation and association, with the aim of improving and learning to learn. The fact is that while knowledge is the result of the selection of information, which accumulates, that is, a person's knowledge is constructed through what they choose based on the information they obtain and that they trust in them (JULIO, 2003).

Added to these facts is the emergence of the Internet, which allows individuals to obtain the most different content and information, including in real time, although it has been increasingly common for many materials to be located that do not correspond to reality and, therefore, fail to add any value to internet users.

RC: 100493

Available in: https://www.nucleodoconhecimento.com.br/education/human-learningprocess 
According to Bruni et al. (2005, p.190), learning occurs effectively from the moment the individual goes through a certain experience, since the numerous brain connections that occur allow the person to associate the facts that happened in his/her surroundings.

In this perspective, Senge (2002, p.32) argues that "all learning is related to action. Learning never occurs exclusively through passive study." Still Bruni et al. (2005) explain that it is through the interaction between people that knowledge expands, individually and collectively. Another relevant aspect highlighted by these authors is the types of learning that add knowledge to individuals, they are: formal or multidisciplinary learning, and informal learning, which takes place in all places and different situations, from the observation of circumstances and interaction between people.

In this sense, Menezes et al. (without date, p.4) report that formal learning takes place based on specific actions regarding the tasks and objectives to be fulfilled, recounting essentially "techniques, methods, conditions and places specified previously and which is intended to originate knowledge, attitudes, skills, behaviors and ideas". Also according to the authors, the formal learning of individuals is elaborated under a method containing organized structures.

In turn, informal learning is, although the relevance of formal learning for individuals, in the context of their personal lives, from the perspective of the organizational environment, is indisputable, the different opportunities and objectives of each company will, in itself, require its employees to have different skills and knowledge, acquired in practical activities, as Flach and Antonello (2010, apud MENEZES et al., undated, p. 4).

In this sense, Menezes et al. (undated, p.4) report Zerbini (2007), to argue that informal learning consists of processes by which people observe formal or informal conversations, whether in work meetings or in relaxed environments.

RC: 100493

Available in: https://www.nucleodoconhecimento.com.br/education/human-learningprocess 
Otherwise, informal learning informal learning takes place when a person has - on his own initiative and for his personal and professional growth - the possibility of learning new visions and attitudes, which will allow that person to make a difference in his professional performance. It is considered one that "happens outside the curricula of courses, educational programs or workshops" (COELHO JÚNIOR and BORGES ANDRADE, 2008, apud MENEZES et al., s. d., p.4).

Another process in the way of learning to learn is the recognition of the differences between people and respect for other life experiences that are recorded in their minds, which directly influence the behavior of these people.

In this sense, Romanowski and Peranzoni (2011) report on the importance of children being taught, from the beginning, to accept the differences between people, in the way they are, think and act; children should be taught to respect diversity, from an early age, to adulthood, and even professional.

The importance of each individual learning and recognizing the differences between people lies in the fact that, in the most varied regions of the country or the world, there are differences in education and training received by individuals at home or school, habits differ, the view on life and about situations and people, differs sexual orientation, and many other aspects are different, from one individual to another (ROMANOWSKI and PERANZONI (2011).

This reality requires that differences in the perception, learning and behavior of different people be accepted by those around them, being very important for the life and business strategy, because good relationship and respect lead to greater productivity and competitiveness in the business environment.

In this regard, still Romanowski and Peranzoni (2011, s.p.) report Perreoud (2000) to state that to learn something new, each person needs to be placed in learning

RC: 100493

Available in: https://www.nucleodoconhecimento.com.br/education/human-learningprocess 
situations frequently; moreover, that these situations make sense to this learner, and that he may feel and mobilize with and for them.

\section{HOW TO DEVELOP THE LEARNING PROCESS IN THE FACE OF ORGANIZATIONAL SKILLS?}

\subsection{BETWEEN THE LINES}

All organizations - regardless of their structure or segment - have an organizational culture that, according to Chiavenato (2010), consists of "habits and beliefs, established by norms, values, attitudes and expectations, shared by all members of the organization. It refers to the system of meanings shared by all members and that distinguishes one organization from the other."

In this sense, Wilbert and Cruz (2014, p. 2), teach that for a company to be effective in its segment of activity, it is fundamental that the thought, values and actions adopted in its context are aligned with the different types of daily challenges, allowing the achievement of the expected results.

Over time, specialists such as Chanlat (1998) have researched human behavior, which is not just about what is observable, since it is also due to other aspects, including the desire, the desire and drive of the individual. Similarly, researchers specialized in organizational management elaborated behavioral analyses in organizations, whose interest was to observe human phenomena from a psychoanalytic culture perspective, suggesting three lines of vision, which were voted by Chanlat (1998) and other authors:

a) linha de visão do grupo: vista como um sistema social de defesa contra a angústia e depressão, que analisa o comportamento despersonificado que até hoje inspira numerosos trabalhos (CHANLAT, 1998 apud JAQUES);

b) linha de visão do dirigente: uma segunda linha de pesquisa que procura destacar não apenas o papel e a importância que o

RC: 100493

Available in: https://www.nucleodoconhecimento.com.br/education/human-learning- 
imaginário exerce nas ações dos dirigentes das empresas, mas também as conseqüências de sua incidência sobre as organizações (CHANLAT, 1998 apud LEVINSON);

c) linha de visão da organização: uma linha que possui uma abordagem na psicologia social, onde vê a relação homem versus conflitos, elucidando até hoje o que - na organização do trabalho - entra em conflito com o funcionamento do aparelho psíquico (CHANLAT, 1998 apud DEJOURS).

These works aim at the need to become aware to understand organizational life, an important management tool. It is through this learning that we can value the inner life and affection that are present in organizational life and how much human relations are fundamentally marked by needs and wills (SOUZA, 2016).

\subsection{COMPETENCE}

The search for learning in organizations by adapting their knowledge, their capacity for a given activity and their decision-making power are the elements necessary to increase the skills of employees in organizations, since, for each position assumed, it is necessary that the whole learning process is very clear, allowing the worker a good performance, and results within the expected (CROZATTI, 1998).

According to the Aurélio Mini Dictionary of the Portuguese Language (FERREIRA, 2008, p. 249), the term competence is defined as: "ability to solve any subject, aptitude, suitability." Based on this definition, it is observed that competence reveals its power when seized, that is, learned, understood and understood, and when there are transformations of the world of work, whether in companies or in society.

Defining individual topics necessary for good performance in each occupation is not enough for innovations to occur or new skills to be developed for companies. The position and occupation define the qualification, or the knowledge or knowledge of each individual can be classified by the educational system. The concept of competence seeks the path of proactivity, being always ahead anticipating and dominating what is happening and what is to come, is not limited, therefore, to a

RC: 100493

Available in: https://www.nucleodoconhecimento.com.br/education/human-learning- 
stock of theoretical and empirical knowledge held by the individual, as it is not implicit in the task (EBERT; POSSAMAI AND SIMON, 2017).

Seeing competence as practical intelligence of acquired and transformed knowledge, a new standard of competence emerges, presented by Fleury and Oliveira Júnior (2001, apud ZARIFIAN, 2001):

a) necessidade de se antecipar aos fatos e às situações: as quais podem - de alguma forma - tumultuar o bom andamento das atividades e a capacidade de resolver as situações e problemas, para garantir o bom andamento do trabalho;

b) necessidade de comunicação e entendimento: do objetivo organizacional usando de empatia, para 0 alinhamento $e$ partilhamento da cultura organizacional e cumprimento das normas da empresa. Neste sentido, Jean François Chanlat (1998) explica que a comunicação é absolutamente necessária, significando inclusive que - na maior parte do tempo - significa transmitir informação, sendo possível essa comunicação de várias maneiras: por meio de atitudes, de gestos, de modos de vestir, por meio de objetos colocados à nossa volta ou que manipulamos, de espaços organizados etc.;

c) noção de um serviço: entender um cliente independente de ser um cliente interno ou externo sempre precisa ser o foco central das atividades e para que isto ocorra, se faz fundamental a comunicação.

Within an organization, work ceases to be a set of tasks and becomes the sum of the skills and competencies used to solve various situations, since they are increasingly profitable and complex professional skills. This complexity of situations makes the unforeseen increasingly common in the day-to-day (LIMA; ZAMBRONI-DE-SOUZA and ARAÚJO, 2015).

When thinking about the organization and its totality and not only in production activities, the main focus of the analysis (FLEURY and OLIVEIRA JÚNIOR, 2001, apud ZARIFIAN, 2001) we observe the need to introduce two other mentions related to mutations in the world of work:

RC: 100493

Available in: https://www.nucleodoconhecimento.com.br/education/human-learning- 
a) âmbito de atuação da organização: local, regional, nacional ou global: as mudanças de operações da empresa, nesses últimos anos em função do processo de globalização têm implicações significativas para a localização e a formação de competências não só em termos da organização. Percebe-se que essa visão está em todos os níveis (com diferentes ponderações e significações), fazendo parte da competência individual;

b) antes da visão estratégica: ficava no topo das organizações, mas atualmente deve estar em diferentes níveis com significação e critério distintos, compondo o perfil da competência individual.

The competence of the individual is not a state, it is not only an exact knowledge, but it places it as a result of the crossing of three axes: the formation of the person (his biography and socialization), his educational education and his professional experience (FLEURY and FLEURY, 2004, apud LE BOTERF, 1997).

Competence is a responsible way of acting with such recognition by others. It emerges as: knowing how to learn, knowing how to engage, taking responsibility, having a strategic vision, adding economic value to the organization and social value for the individual.

Competencies generate economic value for organizations, as well as due social value to the individual; thus, we can say that organizational competence is a portfolio of competencies, physical (infrastructure), financial, intangible, corporate (human resources), the latter being what we believe to be the great differential that creates competitive advantages and in this way, we must have competitive strategies given by these resources. According to Fleury and Fleury (2004), "a resource is something that the organization has or has access to, even if this access is temporary [...] a competency is built from a set of 'blocks' called resources".

Competence is the intelligence of reconciling, mixing and including resources in products and services. The competitiveness of an organization would be fully linked in the interaction between organizational competence and competitive strategy in this way, the resource approach makes the process of formulating the strategy and the

RC: 100493

Available in: https://www.nucleodoconhecimento.com.br/education/human-learning- 
formation of competencies form a circle that feeds back (FLEURY and FLEURY, 2004).

The core competencies offer real benefits to consumers, benefits that are difficult to imitate, and that give access to different markets, and when the company defines its competitive strategy, it ends up identifying its essential business competencies and the necessary competencies of each function - organizational skills (FLEURY and FLEURY, 2004).

From this perspective, it is verified that companies of various organizational competencies (collective competencies associated with middle activities and endactivities) in several areas; however, only a few are the essential competencies, that is, they are those that differentiate them and guarantee a sustainable competitive advantage over other organizations. To be considered an essential competence, it must be directly linked to organizational learning processes, which gives focus and repositions competitive strategies (FLEURY and FLEURY, 2004).

There are three types of strategy that can be adopted by organizations, through which companies compete in the market, according to Fleury and Fleury (2004):

a) excelência operacional: empresas que competem baseadas no custo, oferecendo aos seus clientes produtos com o melhor preço e atendimento adequado;

b) inovação no produto: empresas que oferecerem aos seus clientes produtos de ponta, inovando sempre;

c) orientada para clientes: característica de empresas voltadas a atender a demanda de clientes específicos, e antecipar as necessidades desses clientes, em função de sua proximidade com os mesmos.

Once the competitive strategy is defined, the company is able to identify the core competencies of the business, as well as the skills necessary for each function. This practice allows its board to move from the strategic level to the level of training of the individual's competencies, competencies categorized by Fleury and Oliveira Júnior

RC: 100493

Available in: https://www.nucleodoconhecimento.com.br/education/human-learning- 
(2001) in three large blocks that involve the relationship of the individual with the entire organization:

a) competências de negócio: relacionadas ao negócio em si, seu mercado, clientes, concorrentes;

b) competências técnico-profissionais: habilidades específicas para a realização de determinada operação;

c) competências sociais: competências necessárias para interagir com as pessoas, entre elas a competência interdisciplinar necessárias a acordos, à comunicação, à liderança, e ao respeito às culturas distintas.

Communication is of paramount importance because it ensures the understanding of messages by the other members of the organization; it consists of the ability to express ideas clearly, using communication techniques appropriate to each situation (CHIAVENATO, 2000).

Through communication, one should have the ability to discuss, stimulate and positively influence other people to collaborate, effectively, so that organizational objectives are achieved, conducting consensus processes, focusing on satisfactory results for the parties involved and, mainly, for the organization. Such tools are valid for external and internal situations, such as the ideal way of arguing, so that it allows people to persuasion in the sale of ideas and accept divergent points of view from their initial vision (CROZATTI, 1998).

Teamwork should create and work with groups of people who have diverse and complementary skills and knowledge, providing the emergence of synergy, which is the ability to keep such groups working together efficiently, controlling excessive participations and inviting silent members to participate, resolving conflicts (CHIAVENATO, 2000).

Discussions about learning in organizations are more strongly based on the intellectual perspective, evidencing behavioral changes. The way people manifest

RC: 100493

Available in: https://www.nucleodoconhecimento.com.br/education/human-learningprocess 
and develop the fundamental competencies within the organization and its professional project, is something that occurs only through the process of developing their competencies (CHIAVENATO, 2000). It is a set of learning situations that can lead to the transformation of learning into competencies; as a result, the sum of value will occur for both the person and the organization.

It is a process that can occur at different levels, as Fleury and Fleury (2004) highlight:

a) ao nível individual: que é onde ocorre primeiro, e como já citado, em um indivíduo que é carregado de emoções positivas ou negativas, por meio dos caminhos que percorreu;

b) ao nível grupal: onde a aprendizagem pode vir a se constituir em um processo social e coletivo, sendo que para compreendê-lo é importante entender como é o aprendizado do grupo, como são integradas as crenças individuais com o grupo e, como transformam esse compartilhamento em ações, além do desejo de pertencer ao grupo, que pode constituir um elemento motivacional ao processo de aprendizagem;

c) em nível organizacional: o processo de aprendizagem individual, de compreensão e interpretação compartilhados pelo grupo, torna-se institucionalizado e conhecido em vários mecanismos organizacionais, ou seja, estrutura, regras, procedimentos, e até mesmo em elementos simbólicos, já que, assim como o indivíduo, as organizações também expandem as memórias que possuem informações e as recuperam.

At this stage, it is worth analyzing the learning processes. With regard to the organizational learning process, it is the type that implies the elaboration of knowledge maps, which make it possible to understand what occurs in the external and internal environment of the organization, as well as in the determination of new procedures, which prove the effectiveness of learning (FLEURY and FLEURY, 2004).

For this, organizations rely on their knowledge and memory systems, which allows them to develop routines and procedures to deal with problems. Such procedures are visible ly incorporated into organizational memory.

RC: 100493

Available in: https://www.nucleodoconhecimento.com.br/education/human-learning- 
The change in process, structures or procedures are indicators that learning occurred, adding to the ease of this knowledge being recovered by the members of the organization. According to Fleury and Fleury (2000), "it is tacit, sometimes unconscious knowledge, that rests on organizational memory". In this sense, the learning process has many facets:

a) "Aprendizagem organizacional é um processo de identificação e correção de erros" (ARGYRIS, 1997, p.116 apud FLEURY e FLEURY, 2000, p. 9);

b) "Aprendizagem organizacional significa um processo de aperfeiçoar as ações pelo melhor conhecimento e compreensão" (FIOL E LYLES, 1985, p.803 apud FLEURY e FLEURY, 2000, p. 9);

c) "organizações que aprendem são organizações capacitadas em criar, adquirir e transferir conhecimentos e modificar seus comportamentos para refletir esses novos conhecimentos e "insights'" (GARVIN, 1993, p.80 apud FLEURY e FLEURY, 2000, p.9);

d) "Uma organização está continuamente expandindo sua capacidade de criar o futuro" (SENGE, 1990, p.14 apud FLEURY e FLEURY, 2000, p.9).

An organization learns when its ability to adapt to change is accelerated, constituting the first step in the learning process. The desire to learn goes further: it is innovative and fruitful.

\section{CONCLUSION}

Through the analysis of the theories selected for the elaboration of this study, it is verified that the learning processes involve different aspects - both personal and professional, so that learning within organizations develops within the perspectives of their direction.

If, on the one hand, personal experiences, formal education and characteristics of the personality of individuals collaborate for their personal formation, they are elements that will add to the characteristics, guidelines and work systems existing within the

RC: 100493

Available in: https://www.nucleodoconhecimento.com.br/education/human-learning- 
companies, and it is necessary that each worker (to) adapts in the best way, besides identifying the existences of possibilities of expansion of their skills and creativity - or not - according to organizational expectations.

\section{REFERENCES}

BEZERRA, Alan André Aparecido; OLIVEIRA, Ednilson Barbosa de. Aprendizagem Organizacional: a organização que aprende. Artigo publicado em 06 jul 2006. Disponível em: [https://administradores.com.br/artigos/aprendizagem-organizacionala-organizacao-que-aprende]; acesso em 28 mar 2021.

BRUNI, Márcia; TURRIONI, João Batista; STANO, Rita de Cássia Trindade. Abordagens da aprendizagem no contexto organizacional. II Simpósio de Excelência em Gestão e Tecnologia - SEGeT'2005. p. 190-198. Disponível em: [https://www.aedb.br/seget/arquivos/artigos05/274 Abordagens\%20da\%20aprendiza gem\%20no\%20contexto\%20organizacional.pdf]; acesso em 28 mar 2021.

CHANLAT, Jean François. 0 indivíduo na Organização. 1.ed. São Paulo: Atlas, 1998, v.3.

CHIAVENATO, Idalberto. Recursos humanos - 0 capital humano das organizações. 11.ed. São Paulo: Atlas, 2020.

Gestão de pessoas: o novo papel dos recursos humanos nas organizações. 3.ed. Rio de Janeiro: Elsevier, 2010.

CROZATTI, Jaime. Modelo de Gestão e Cultura Organizacional - conceitos e interações. Caderno de Estudos, SP, FIPECAFI, vol. 10, n. 18, maio/ago 1998.

DRUCKER, Peter F. Administrando em Tempos de Grandes Mudanças. São Paulo: Pioneira, 1999.

RC: 100493

Available in: https://www.nucleodoconhecimento.com.br/education/human-learningprocess 
EBERT, Luis Augusto; POSSAMAI, Cleide Tirana Nunes; SIMON, Vanessa Silveira. Perspectivas profissionais. Indaial: UNIASSELVI, 2017. Disponível em: [https://www.uniasselvi.com.br/extranet/layout/request/trilha/materiais/livro/livro.php? codigo=25048]; acesso em 03 abr 2021.

FERREIRA, Aurélio Buarque de Holanda. Miniaurélio: o minidicionário da língua portuguesa. 7.ed. Curitiba: Positivo, 2008.

FLEURY, Afonso C. C.; FLEURY, Maria Tereza Leme. Estratégias Competitivas E Competências Essenciais: Perspectivas Para A Internacionalização Da Indústria No Brasil. Gestão \& Produção, vol.10, n.2, p.129-144, ago. 2003. Disponível em:

[https://www.scielo.br///gp/a/C8hMY4qXzCfGWd4v8VRwXJQ/?lang=pt]; acesso em 28 mar 2021.

FLEURY, M. Teresa Keme; OLIVEIRA JR., Moacir de M. (Coord.). Gestão estratégica do conhecimento: integrando aprendizagem, conhecimento e competências. São Paulo: Atlas, 2001.

GUNS, Bob. A organização que aprende rápido: seja competitivo utilizando o aprendizado organizacional. São Paulo: Futura, 1998.

HOUAISS, Antonio; VILLAR, Mauro de Salles; FRANCO, Francisco Manoel de Mello. Pequeno Dicionário Houaiss da Língua Portuguesa. 1.ed. São Paulo: Moderna, 2015.

JULIO, Carlos Alberto. A Magia dos Grandes Negociadores. 1.ed. Rio de Janeiro: Elsevier, 2003.

LIMA, Claudia Maria Pereira de; ZAMBRONI-DE-SOUZA, Paulo César; ARAÚJO, Anísio José da Silva. A Gestão do Trabalho e os Desafios da Competência: uma Contribuição de Philippe Zarifian. Psicologia: Ciência e Profissão, vol. 35, n. 4, p.

RC: 100493

Available in: https://www.nucleodoconhecimento.com.br/education/human-learningprocess 
1223-1238,

2015.

Disponível

em:

[https://www.scielo.br/j/pcp/a/xxL7S4fWDxwkKWmkB4rtTWp/abstract/?lang=pt]; acesso em 28 mar 2021.

MENEZES, Bárbara Sampaio de; CABRAL, Augusto Cézar De Aquino; SANTOS, Sandra Maria dos; SILVA, Maria Naiula Monteiro da. Aprendizagem individual no contexto organizacional: percepção dos estudantes da FEAAC - UFC. Artigo publicado nos Anais do ENGEMA - Encontro Internacional sobre Gestão Empresarial e Meio Ambiente. Disponível em: [http://engemausp.submissao.com.br/17/anais/arquivos/81.pdf]; acesso em 28 mar 2021.

PERRENOUD, Philippe. Dez novas competências para ensinar: convite à viagem. Porto Alegre: Artes Médicas, 2000.

ROMANOWSKI, Caroline Leonhardt; PERANZONI, Vaneza Cauduro. Educação para diversidade humana: respeito às diferenças $e$ valorização da singularidade. EFDeportes.com, Revista Digital. Buenos Aires - Año 16 - № 158 julho de 2011. Disponível em: [https://www.efdeportes.com/efd158/educacao-paradiversidade-humana.htm]; acesso em 03 abr 2021.

SENGE, Peter

M. A Quinta Disciplina: Arte e Prática da Organização que aprende. 10. ed. São Paulo: Best Seller, 2002.

WILBERT, Alison; CRUZ, Hélio Alves da. Cultura e Clima Organizacionais: uma análise na empresa Novo Trigo de Balneário Camboriu/SC. XI SEGeT - Simpósio de Excelência em Gestão e Tecnologia, de 22 a 24 de outubro de 2014. Disponível em: [https://www.aedb.br/seget/arquivos/artigos14/45120574.pdf]; acesso em 28 mar 2021.

Submitted: March, 2021.

RC: 100493

Available in: https://www.nucleodoconhecimento.com.br/education/human-learningprocess 
Approved: October, 2021.

RC: 100493

Available in: https://www.nucleodoconhecimento.com.br/education/human-learningprocess 